\title{
INTERCROPPING BARLEY WITH BERSEEM CLOVER UNDER DIFFERENT SEEDING RATES
}

\author{
FADIA M. SULTAN ${ }^{1}$ and WAFAA W. M. SHAFIE ${ }^{2}$ \\ 1. Forag Crops Res.Dept., Field Crops Res. Institute, ARC, Giza, Egypt. \\ 2. Cent. Lab. For Design \& Stat. Analysis ReS., ARC, Giza, Egypt.
}

(Manuscript received 28 June 2015)

\begin{abstract}
$\Lambda$ field experiment was conducted in the experimental farm of Agricultural Research Station at Giza during the two successive growing seasons 2012/2013 and 2013/2014 to intercrop barley with berseem clover under different seeding rates. The study was conducted using four cultivars of barley, two of them are Hulled barley Giza 133 and Giza 134 and two are hull-less barley Giza 129 and Giza 130 and two berseem clover cultivars Helaly and Sakha 4 as sole crops and intercrop planted at three seeding rates i.e., $37.5-6.25,25-12.5$ and $12.5-18.75$ seeds kg/fad ${ }^{-}$ ${ }^{1}$. The experimental designs were a Randomize Complete Block Design (R. C. B. D) in three replicates. Data showed that, total yield of dry matter (DM) and fresh yield hull-less barley cultivar Giza 129 and be seem cultivar Sakha-4 had the highest values in barley and berseem cultivars. In intercropped barley with berseem clover Giza 134 - Helaly provided total dry matter and fresh forage yield was greater value for intercropped barley - berseem at intercropping system (12.5-18.75 seeds $\left.\mathrm{kg}^{-} \mathrm{fad}^{-}\right)$. Data showed that, Berseem in pure stand consistently had the highest crude protein concentration for Helaly cultivars. Barley in pure stand consistently had the highest CP concentration for barley cultivar Giza 129 (hull-less barley). Intercropping barley Giza 129 with berseem clover Helaly at intercropping system ( $25 \%$ for barley cultivar Giza $129+75 \%$ for bersem cultivar Helaly had the highest value for the crude protein. Sole berseem possessed higher calcium and phosphorus level that c $v$ Sakha 4. The highest values calcium and phosphorus was recognized for Giza 133 at sole at over two seasons. Intercropping by $25 \%$ G. $133-$ Sakha 4 (75\%) in both two seasons had the highest value of calcium and phosphorus.
\end{abstract}

Keywords: Barley, Berseem clover, Intercropping, dry matter.

\section{INTRODUCTION}

Intercropping cereals with legumes forage or food production is used in many parts of the world for soil conservation. Intercropping including legumes is known to use resources more efficiently Anil et al., 1998; Papastylianou, (2004). Monocultures of legumes or cereals do not provide in some cases satisfactory results for forage production (Osman and Nersoyan, 1986). In particular, forage quality of cereals is small grain cereals provides high yields in terms of dry matter dry matter (DM) but they produce forage with low crude protein (CP) (Lawes and Jones, 1971). In 
intercrops, compaction cereals provide structural support for legume growth, improve light interception, and facilitate mechanical harvest, while legumes generally increase the protein and mineral content of forage (Robinson, 1969). Crop species, seeding rates, and competition between mixture components may affect yield and quality of forage produced by intercrops (Caballero et al. 1995). The main use of barley in Egypt is for animal feed. Recently, a new interest was born for using barley grain as human food. Growers grow barley in Egypt to produce the crop as dual purposes, i. e., for feed and food. Barley biomass (straw and grains) is used as forage. Berseem or Egyptian clover Trifolium alexanderinum $\mathrm{L}$. is an annual legume with climbing growth habit, great productivity due to its high growth rate and good fodder recovery after cutting, and high levels of crude protein (CP). Berseem clover forage may cause livestock bone abnormalities due to its incorrect ratio of Ca to $\mathrm{P}$ (Hall et al., 1991) and bloat. The effects of seeding rates on forage yield and quality of this intercrop are also limited in the literature. Furthermore, competition indices have not been used in berseem clover-barley intercropping systems to evaluate the competition between these species and their possible advantage in using the environmental resources.

The objectives of this study were to evaluate the fresh forage yield, dry forage yield and chemical constituents (\%) of barley cultivated and berseem clover as intercrops at three intercropping systems.

\section{MATERIALS AND METHODS}

A field experiment was conducted in winter season 2012/2013 and repeated in 2013/2014 at Giza Experimental Station Farm, Agricultural Research Center (ARC) to determine the most productive intercrop of berseem clover with barley for fresh forage yield (ton/fad), dry forage yield (ton/fad) and chemical forage analyses for solid barley, solid berseem and intercropped barley with berseem under different seeding rates. Physical and chemical analysis of soil at Giza in the two seasons (Table 1).

Table 1. Physical and chemical analysis of the experimental soil at Giza in two winter seasons 2012-2013 and 20132014.

\begin{tabular}{|c|c|c|c|c|c|c|c|c|c|c|}
\hline \multirow{2}{*}{ Years } & \multicolumn{2}{|c|}{ Availabl (ppm) } & \multirow{2}{*}{$\mathrm{PH}$} & $\begin{array}{c}\text { Ecmm } \\
\mathrm{h} / \mathrm{cm}\end{array}$ & Caco 3 & Clay\% & Silt\% & Faine\% & Soile \\
& & $\mathrm{N}$ & $\mathrm{P}$ & $\mathrm{K}$ & & & & & & \\
texture*
\end{tabular}

*Textural classes according to the triangular diagram.

C. F. Soile and Water Research Institute, A. R. C. Egypt. 
The experimental design was a Randomized Complete Block Design (R. C. B. D) with three replicates. Each block contained 30 treatments. Four barley cultivars, two hulled barley (Giza 133 and 134) and two hull-less barley (Giza 129 and 130), as well as two berseem clover cultivars Sakha 4 and Helaly were included in the study. Barley and berseem clover were planted alone at seeding rates of $50 \mathrm{~kg} \mathrm{fad}^{-1}$ and 25 $\mathrm{kg} \mathrm{fad}^{-1}$, respectively. Barley-berseem clover intercropped at three seeding rates $(75+25 \%),(50+50 \%)$ and $(25+75 \%)$, respectively, (4 barley $\times 2$ berseem $\times 3$ seeding rate total $=24+6$ sole $=30$ treatments. The plot size was $6.4 \mathrm{~m}^{2}$ each of plot was containing of 16 rows for intercropping system $(3.2 \mathrm{~m}$ wide rows spaced $20 \mathrm{~cm}$ apart with $2 \mathrm{~m}$ long). The sowing dates were done on the $2^{\text {nd }} 8^{\text {th }}$ of November in the two seasons, respectively. The intercropping systems was and in alternate rows with barley and berseem. All plots received $30 \mathrm{P}_{2} \mathrm{O}_{5} \mathrm{~kg} / \mathrm{fad}$ before sowing. Potassium sulphate $\left(48 \% \mathrm{~K}_{2} \mathrm{O}\right)$ was added at the rate of $50 \mathrm{~kg} / \mathrm{fad}$. Nitrogen fertilizer was added as ammonium nitrate $(33.5 \% \mathrm{~N})$ at rate of $60 \mathrm{kgN} /$ fad. The $\mathrm{N}$ fertilizer was divided into four equal doses and the first dose was applied after 15 days from seeding, then after each cut prior to irrigation. Four cuts were taken after 6, 12, 16 and 20 weeks (during 140 days) from sowing in both seasons. Data were statistically analyses according to procedure outlined by Snedecor and Cochrn (1980), using MSTAT-C computer program ver.4 (1986).

\section{Studied characters included:-}

A- Fresh forage yield (ton/fad $\left.{ }^{-1}\right)$ :- plants were hand clipped and weighted in $\mathrm{kg} /$ plot then, converted to ton $/ \mathrm{fad}^{-1}$.

B- Dry forage yield (ton/fad $\left.{ }^{-1}\right):-100 \mathrm{~g}$ plant samples from each plot were dried at $105^{\circ} \mathrm{C}$ till constant weight and dry matter percentage (DM \%) was estimated. The dry forage yield (ton/fad) was calculated by multiplying fresh forage yield $\left(\right.$ ton/fad $\left.{ }^{-1}\right) X$ dray matter percentage (DM\%) (Norman and Jarvis, 1975).

C- Chemical composition:- Chemical analysis followed the conventional methods outlined by A. O. A. C. (1980). Plant samples of each cut in both seasons were dried, for chemical analysis. Samples were analyzed in the Forage Crops Research Dep. Lab at Giza to determine crude protein (CP), crude fiber (CF), ash and calcium (Ca) and phosphorus (P) were detected at Region al Center for Food and Feed (RCFF), ARC. Statistical analysis: All obtained results were statistically analyzed to compare the means through L.S.D.test at probability of 0.05 as described by Gomez and Gomes (1984). 


\section{RESULTS AND DISCUSSION}

In general, the data showed significant differences regard fresh and dry forage matter yield for cuts, treatments and the interaction among treatments and cuts at the two seasons (Tables 2 and 3 ).

\section{Fresh forage yield}

Results as mean performance of fresh forage yield for the individual cuts and total fresh forage yield of the investigated crops in two seasons are presented in Table (2). Total fresh forage yield of pure stand berseem clover Sakha 4 and Helaly was superior for (54.81 and $49.11 \mathrm{t} / \mathrm{fed}^{-1}$ ), respectively, to those of barley Giza 133, Giza 134 (hulled barley), Giza 129 and Giza 130 (hull-less barley) 18.40, 17.48, 23.65 and $18.56 \mathrm{t} / \mathrm{fed}^{-1}$, respectively. This superiority could be attributed to better persistence for berseem clover cultivars compared to barley cultivars that were reflected in two extra cuts from berseem clover cultivars per season. Berseem clover cultivars provided four cuts per season, while barley plants vanished after two cut (Table 2). It is worthy rote that fresh forage yield of first cut of pure stand barley, averaged over varieties, exceeded that of berseem clover cultivars, but sharply declined thereafter (Table 2). However, yield of cv. Giza 129 was consistently the highest barley cultivar. The highest fresh forage yield of the first cut of pure stand barley was given by c.v. Giza $129\left(17.65 \mathrm{t} / \mathrm{fed}^{-1}\right)$. Also hull-less barley cultivar Giza $129\left(23.65 \mathrm{t}_{/} \mathrm{fad}^{-1}\right)$ had the highest value in total fresh forge for barley cultivars. In Table (2) data showed that, in intercropping system $25 \%$ barley cv. Giza 134 and $75 \%$ berseem Helaly gave the highest in both first and second season 63.88 and $63.69 \mathrm{t} / \mathrm{fad}^{-1}$, respectively. Concerning, the two cultivars of barley when intercropped with berseem, barley c.v. Giza 134 showed a success as a companion crop with berseem. The obtained results are in agreement with those obtained by Helmy et al. (2011).

\section{Dry forage yield}

Results of dry forage yield for the individual cuts and total yield of the investigated treatments are presented in Table (3). At the first cut in the first season, the dry forage yield obtained by barley sole crop was higher than that berseem sole crop (Table 3). Moreover, Giza 129 had the highest value of dry forage yield obtained by barley sole crop $\left(2.14 \mathrm{ton} / \mathrm{fad}^{-1}\right)$. The total dry forage yields of all intercrops were different from yields of the barley sole crops, but were affected by seeding rates of berseem clover. Also, barley cultivar did affect forage yield in intercrops. The intercropped barley with berseem clover Giza 134 x Helaly provided total dry forage yield was greater value for intercropped barley $\mathrm{x}$ berseem at intercropping system (25-75\%) 6.59 ton/fad ${ }^{-1}$ (Table 3). Similarly, Mattiniello (1999) and Ross et al. (2004 a, 2004b) found that the intercropped berseem clover with barley provided total dry forage yield by 63 and 18 to $180 \%$, respectively, greater than that of berseem clover sole crop. However, Ross et al. (2004 a) found that total dry forage yields of intercrop increased in response to increasing barley density. Regard first cut in the 
second season, berseem clover sole crop provided dry forage yield that different from with those of barley sole crops and most of their intercrops. Giza $134+$ Helaly had greater dry forage yield than for intercropping barley + berseem at intercropping system (25-75\%) (Table 3). Also, dry forage yield obtained from the berseem clover sole crop in second season was greater than that obtained in first season. This may have resulted from increased biological $\mathrm{N}_{2}$ fixation and consequently greater $\mathrm{N}$ uptake (Campillo et al. 2005) that result in more growth. This may also be a result of differences in environmental conditions and interactions.

Table 2. Fresh forage yield (ton/fad) at the four cuts of four barley and two berseem clover cultivars under different intercropping systems ( I. S ) in 2012/2013, 2013/2014 seasons.

\begin{tabular}{|c|c|c|c|c|c|c|c|c|c|c|c|}
\hline \multirow{3}{*}{ Treatments } & \multirow{3}{*}{ I. S } & \multicolumn{5}{|c|}{ Fresh forage (ton/fad) } & \multicolumn{5}{|c|}{ Fresh forage (ton/fad) } \\
\hline & & \multicolumn{5}{|c|}{$2012 / 2013$} & \multicolumn{5}{|c|}{$2013 / 2014$} \\
\hline & & Cut 1 & Cut 2 & Cut 3 & Cut 4 & Total & Cut 1 & Cut 2 & Cut 3 & Cut 4 & Total \\
\hline \multicolumn{12}{|l|}{$\underline{\text { Sole barley }}$} \\
\hline G.133 & $100 \%$ & 13.54 & 4.86 & - & - & 18.40 & 13.44 & 4.79 & - & - & 18.23 \\
\hline G.134 & $100 \%$ & 11.87 & 5.61 & - & - & 17.48 & 11.54 & 5.41 & - & - & 16.95 \\
\hline G.129 & $100 \%$ & 17.65 & 6.00 & - & - & 23.65 & 16.87 & 6.11 & - & - & 22.98 \\
\hline G.130 & $100 \%$ & 13.48 & 5.08 & - & - & 18.56 & 16.75 & 4.99 & - & - & 21.74 \\
\hline \multicolumn{12}{|l|}{$\underline{\text { Sole berseem }}$} \\
\hline Sakha 4 & $100 \%$ & 13.12 & 15.19 & 13.77 & 12.73 & 54.81 & 12.79 & 15.10 & 15.20 & 12.10 & 55.19 \\
\hline Helaly & $100 \%$ & 12.10 & 13.36 & 12.30 & 11.35 & 49.11 & 11.97 & 13.25 & 14.02 & 11.21 & 50.45 \\
\hline \multicolumn{12}{|l|}{$\underline{\text { Intercrops }}$} \\
\hline G.133- Sakha 4 & $75-25 \%$ & 14.11 & 13.63 & 13.23 & 12.60 & 53.57 & 14.02 & 13.31 & 13.28 & 12.10 & 52.71 \\
\hline G.133- Sakha 4 & $50-50 \%$ & 12.29 & 14.40 & 13.03 & 11.23 & 50.95 & 12.39 & 14.11 & 12.88 & 11.13 & 50.51 \\
\hline G.133- Sakha 4 & $25-75 \%$ & 14.80 & 15.91 & 14.86 & 13.69 & 59.26 & 14.47 & 15.23 & 14.22 & 13.88 & 57.8 \\
\hline G.133- Helaly & $75-25 \%$ & 13.52 & 12.56 & 12.02 & 11.33 & 49.43 & 13.12 & 12.20 & 11.87 & 11.15 & 48.34 \\
\hline G.133- Helaly & $50-50 \%$ & 12.08 & 14.93 & 12.68 & 12.00 & 51.69 & 12.14 & 13.52 & 12.41 & 12.00 & 50.07 \\
\hline G.133- Helaly & $25-75 \%$ & 13.80 & 15.24 & 13.21 & 12.13 & 54.38 & 13.42 & 15.10 & 13.01 & 11.75 & 53.28 \\
\hline G.134- Sakha 4 & $75-25 \%$ & 13.64 & 14.43 & 13.91 & 11.78 & 53.76 & 13.88 & 14.22 & 13.75 & 11.22 & 53.07 \\
\hline G.134- Sakha 4 & $50-50 \%$ & 11.77 & 15.10 & 14.13 & 12.92 & 53.92 & 11.70 & 15.40 & 14.95 & 12.33 & 54.38 \\
\hline G.134- Sakha 4 & $25-75 \%$ & 11.48 & 16.71 & 13.82 & 13.69 & 55.7 & 11.85 & 16.78 & 13.77 & 13.45 & 55.85 \\
\hline G.134- Helaly & $75-25 \%$ & 13.65 & 12.83 & 11.29 & 10.33 & 48.1 & 13.88 & 12.66 & 11.71 & 10.01 & 48.26 \\
\hline G.134- Helaly & $50-50 \%$ & 12.00 & 15.10 & 12.00 & 11.59 & 50.69 & 12.41 & 15.41 & 12.14 & 11.63 & 51.59 \\
\hline G.134- Helaly & $25-75 \%$ & 19.44 & 17.73 & 13.88 & 12.83 & 63.88 & 19.75 & 16.98 & 13.95 & 13.01 & 63.69 \\
\hline G.129- Sakha 4 & $75-25 \%$ & 17.06 & 16.83 & 13.79 & 12.13 & 59.81 & 17.54 & 15.33 & 13.53 & 12.14 & 58.54 \\
\hline G.129- Sakha 4 & $50-50 \%$ & 13.61 & 14.66 & 12.87 & 11.80 & 52.94 & 13.52 & 17.96 & 12.74 & 11.93 & 56.15 \\
\hline G.129- Sakha 4 & $25-75 \%$ & 11.76 & 16.98 & 14.34 & 12.20 & 55.28 & 12.48 & 16.22 & 14.22 & 12.45 & 55.37 \\
\hline G.129- Helaly & $75-25 \%$ & 17.17 & 16.56 & 15.32 & 13.72 & 62.77 & 17.52 & 13.88 & 15.73 & 13.89 & 61.02 \\
\hline G.129- Helaly & $50-50 \%$ & 14.21 & 14.00 & 13.77 & 11.54 & 53.52 & 15.33 & 16.01 & 13.52 & 11.74 & 56.6 \\
\hline G.129- Helaly & $25-75 \%$ & 11.17 & 15.70 & 14.32 & 12.51 & 53.7 & 11.65 & 13.58 & 14.87 & 12.89 & 52.99 \\
\hline G.130- Sakha 4 & $75-25 \%$ & 14.30 & 13.40 & 12.62 & 11.59 & 51.91 & 14.85 & 13.89 & 12.93 & 11.76 & 53.43 \\
\hline G.130- Sakha 4 & $50-50 \%$ & 12.80 & 14.13 & 13.82 & 12.73 & 53.48 & 12.97 & 14.89 & 14.11 & 12.56 & 54.53 \\
\hline G.130- Sakha 4 & $25-75 \%$ & 11.82 & 15.40 & 13.95 & 13.14 & 54.31 & 11.78 & 15.66 & 14.96 & 13.78 & 56.18 \\
\hline G.130- Helaly & $75-25 \%$ & 13.72 & 14.70 & 12.43 & 11.91 & 52.76 & 13.89 & 14.11 & 12.74 & 11.17 & 51.91 \\
\hline G.130- Helaly & $50-50 \%$ & 12.34 & 14.32 & 13.06 & 12.81 & 52.53 & 12.76 & 13.01 & 13.84 & 12.95 & 52.56 \\
\hline G.130- Helaly & $25-75 \%$ & 10.85 & 14.00 & 13.43 & 11.93 & 50.21 & 11.25 & 14.66 & 14.53 & 11.25 & 51.69 \\
\hline \multicolumn{2}{|c|}{ C.V\% } & 9.03 & 7.23 & 12.52 & 8.70 & 6.33 & 8.56 & 6.98 & 10.20 & 8.62 & 7.46 \\
\hline \multicolumn{2}{|c|}{ L.SD at 005 for Treatments $(\mathrm{T})$} & 2.83 & 2.46 & 3.45 & 2.35 & 3.54 & 2.16 & 2.28 & 1.93 & 2.35 & 4.56 \\
\hline \multicolumn{2}{|c|}{ L.SD at 005 for cut $(\mathrm{C}$ ) } & 2.97 & 3.12 & 2.61 & 1.27 & 4.22 & 2.91 & 2.57 & 3.08 & 1.93 & 3.58 \\
\hline \multicolumn{2}{|c|}{ L.SD at 005 for $T X C$} & 2.43 & 2.57 & 2.85 & 1.94 & 3.40 & 1.79 & 1.89 & 1.60 & 1.94 & 4.71 \\
\hline
\end{tabular}


Table 3. Dry forage yield (ton/fad) at the four cuttings of four barley genotypes and two berseem clover cultivars under different intercropping systems ( I. S) in 2012/2013, 2013/2014 seasons.

\begin{tabular}{|c|c|c|c|c|c|c|c|c|c|c|c|}
\hline \multirow{3}{*}{ Treatments } & \multirow{3}{*}{ I. S } & \multicolumn{5}{|c|}{ Dry forage (ton/fad) } & \multicolumn{5}{|c|}{ Dry forage (ton/fad) } \\
\hline & & \multicolumn{5}{|c|}{$2012 / 2013$} & \multicolumn{5}{|c|}{$2013 / 2014$} \\
\hline & & Cut 1 & Cut 2 & Cut 3 & Cut 4 & Total & Cut 1 & Cut 2 & Cut 3 & Cut 4 & Total \\
\hline \multicolumn{12}{|l|}{ Sole barley } \\
\hline G.133 & $100 \%$ & 1.89 & 1.10 & - & - & 2.99 & 1.92 & 1.25 & - & - & 3.17 \\
\hline G.134 & $100 \%$ & 1.87 & 1.16 & - & - & 3.03 & 1.48 & 1.02 & - & - & 2.5 \\
\hline G.129 & $100 \%$ & 2.14 & 1.75 & - & - & 3.89 & 2.10 & 1.87 & - & - & 3.97 \\
\hline G.130 & $100 \%$ & 1.93 & 1.41 & - & - & 3.34 & 2.01 & 1.80 & - & - & 3.81 \\
\hline \multicolumn{12}{|l|}{ Sole berseem } \\
\hline Sakha 4 & $100 \%$ & 1.25 & 1.62 & 1.34 & 1.05 & 5.26 & 1.38 & 1.85 & 1.45 & 1.13 & 5.81 \\
\hline Helaly & $100 \%$ & 1.18 & 1.73 & 1.20 & 1.98 & 6.09 & 1.23 & 1.96 & 1.33 & 1.55 & 6.07 \\
\hline \multicolumn{12}{|l|}{ Intercrops } \\
\hline G.133- Sakha 4 & $75-25 \%$ & 1.76 & 1.23 & 1.15 & 1.07 & 5.21 & 1.66 & 1.01 & 1.11 & 1.17 & 5.0 \\
\hline G.133- Sakha 4 & $50-50 \%$ & 1.54 & 1.66 & 1.42 & 1.35 & 5.97 & 1.81 & 1.54 & 1.47 & 1.42 & 6.2 \\
\hline G.133- Sakha 4 & $25-75 \%$ & 1.44 & 1.73 & 1.66 & 1.51 & 6.34 & 1.83 & 1.70 & 1.59 & 1.23 & 6.3 \\
\hline G.133- Helaly & $75-25 \%$ & 1.65 & 1.45 & 1.16 & 1.03 & 5.29 & 1.75 & 1.25 & 1.10 & 0.98 & 5.1 \\
\hline G.133- Helaly & $50-50 \%$ & 1.53 & 1.31 & 1.20 & 1.13 & 5.17 & 1.42 & 1.45 & 1.16 & 1.01 & 5.0 \\
\hline G.133- Helaly & $25-75 \%$ & 1.69 & 1.42 & 1.30 & 1.21 & 5.62 & 1.83 & 1.71 & 1.33 & 1.17 & 6.0 \\
\hline G.134- Sakha 4 & $75-25 \%$ & 1.89 & 1.61 & 1.31 & 1.19 & 6.00 & 1.96 & 1.54 & 1.42 & 0.86 & 5.8 \\
\hline G.134- Sakha 4 & $50-50 \%$ & 1.64 & 1.42 & 1.19 & 1.00 & 5.25 & 1.53 & 1.32 & 1.22 & 1.01 & 5.1 \\
\hline G.134- Sakha 4 & $25-75 \%$ & 1.51 & 1.44 & 1.36 & 1.20 & 5.51 & 1.55 & 1.21 & 1.45 & 1.14 & 5.4 \\
\hline G.134- Helaly & $75-25 \%$ & 1.94 & 1.31 & 1.10 & 1.06 & 5.41 & 1.89 & 1.75 & 1.17 & 1.00 & 5.8 \\
\hline G.134- Helaly & $50-50 \%$ & 1.81 & 1.63 & 1.50 & 1.30 & 6.24 & 1.73 & 1.79 & 1.59 & 1.17 & 6.3 \\
\hline G.134- Helaly & $25-75 \%$ & 1.68 & 1.94 & 1.62 & 1.35 & 6.59 & 1.65 & 1.91 & 1.68 & 1.20 & 6.47 \\
\hline G.129- Sakha 4 & $75-25 \%$ & 1.82 & 1.49 & 1.29 & 1.18 & 5.78 & 1.96 & 1.53 & 1.27 & 1.05 & 5.8 \\
\hline G.129- Sakha 4 & $50-50 \%$ & 1.59 & 1.43 & 1.31 & 1.06 & 5.39 & 1.77 & 1.36 & 1.35 & 1.00 & 5.5 \\
\hline G.129- Sakha 4 & $25-75 \%$ & 1.86 & 1.62 & 1.42 & 1.21 & 6.11 & 1.89 & 1.76 & 1.49 & 1.11 & 6.3 \\
\hline G.129- Helaly & $75-25 \%$ & 1.57 & 1.39 & 1.29 & 1.13 & 5.38 & 1.47 & 1.54 & 1.38 & 1.00 & 5.4 \\
\hline G.129- Helaly & $50-50 \%$ & 1.53 & 1.33 & 1.18 & 1.00 & 5.04 & 1.87 & 1.44 & 1.22 & 0.96 & 5.5 \\
\hline G.129- Helaly & $25-75 \%$ & 1.68 & 1.35 & 1.22 & 1.13 & 5.38 & 1.93 & 1.63 & 1.37 & 1.02 & 6.0 \\
\hline G.130- Sakha 4 & $75-25 \%$ & 1.89 & 1.46 & 1.33 & 1.11 & 5.79 & 1.85 & 1.79 & 1.47 & 1.00 & 6.1 \\
\hline G.130- Sakha 4 & $50-50 \%$ & 1.65 & 1.35 & 1.15 & 1.03 & 5.18 & 1.66 & 1.44 & 1.25 & 0.87 & 5.2 \\
\hline G.130- Sakha 4 & $25-75 \%$ & 1.58 & 1.48 & 1.33 & 1.15 & 5.54 & 1.70 & 1.56 & 1.45 & 1.10 & 5.8 \\
\hline G.130- Helaly & $75-25 \%$ & 1.80 & 1.60 & 1.28 & 1.16 & 5.84 & 1.65 & 1.86 & 1.31 & 1.11 & 5.9 \\
\hline G.130- Helaly & $50-50 \%$ & 1.76 & 1.46 & 1.35 & 1.15 & 5.72 & 1.85 & 1.52 & 1.48 & 1.00 & 5.9 \\
\hline G.130- Helaly & $25-75 \%$ & 1.88 & 1.55 & 1.40 & 1.23 & 6.06 & 1.98 & 1.68 & 1.56 & 1.15 & 6.4 \\
\hline \multicolumn{2}{|c|}{ C.V\% } & 10.66 & 5.20 & 11.88 & 9.36 & 12.33 & 11.69 & 9.33 & 8.40 & 7.66 & 9.11 \\
\hline \multicolumn{2}{|c|}{$\begin{array}{l}\text { L.SD at } 005 \text { for Treatments } \\
\qquad(\mathrm{T})\end{array}$} & 2.33 & 2.28 & 2.39 & 2.45 & 5.22 & 2.84 & 3.13 & 2.69 & 2.77 & 4.12 \\
\hline \multicolumn{2}{|c|}{ L.SD at 005 for cut ( C ) } & 1.53 & 1.93 & 1.50 & 2.37 & 2.96 & 2.87 & 2.43 & 2.90 & 2.07 & 3.55 \\
\hline \multicolumn{2}{|c|}{ L.SD at 005 for $T X C$} & 2.26 & 2.21 & 2.23 & 2.36 & 3.84 & 2.35 & 2.58 & 2.22 & 2.29 & 3.89 \\
\hline
\end{tabular}

\section{Chemical composition}

The ANOVA for protein \%, fiber\%, \%ash, calcium and phosphorus yields of the cuts, sole crops or the intercrops (treatments) and interaction between treatments indicated significantly differences (Table 4). Bartlett's test was done to test the homogeneity of error variance. The test was not significant for all assessed traits, so, the two season data were combined. 


\section{Crude protein (CP)\%}

Expressing protein content which combines the CP percentage, (one of the most important quality characters) and the total dry forage yield produced is a valuable measure because it is important to know the total protein which can be harvested in a forage crop in livestock enterprises (Caballero et al., 1995). The investigated treatments varied significantly in crude protein content, within and among cuts (Table 4). Berseem in pure stand consistently had the highest crude protein concentration for Helaly cultivars which ranged from 16.98 in the first cut to $13.01 \%$ in the forth cut. Barley in pure stand consistently had the highest CP concentration for barley cultivar Giza 129 ( hull-less barley) which ranged from 12.85 in the first cut to $13.02 \%$ in the last cut grown as sole crop over the two season. At the first cut and the last cut over the two season, the protein yield of barley Giza 129 (hull-less barley) followed by Giza 130 (hull-less barley) cut were greater than that of barley Giza 133 (hulled barley) and Giza 134 (hulled barley) (Table 4). While, sole berseem clover cultivars (Sakha4 and Helaly) provided greater protein yield than the barley cultivars sole crop over the two season. Intercropping barley Giza 129 with berseem clover Helaly at intercropping system (25\% for barley cultivar Giza $129+$ $75 \%$ for bersem cultivar Helaly ( $14.33 \%$ ) had the highest value for the crude protein. While the barley cultivars in pure stand consistently had less in crude protein concentrations in comparison with berseem cultivars. Crude protein level declined over time as the stand aged. The higher values of crude protein in berseem may due to the symbiotic fixation, which is reflected in the high number and dry weight of nodules. McAndrews, et al., (2004) reported that berseem fixed about $188 \mathrm{~kg} \mathrm{~N} \mathrm{ha}^{-1}$ when measured with $\mathrm{N}^{15}$. In addition, legumes have greater leaves to stem ratio which is a primary sites of photosynthesis and enzymes activity.

\section{Crude fiber\%}

Crude fiber of pure stand barley was the highest in the first cut and declined as the stand aged. Crude fiber of barley, averaged over cultivars, ranged from 29.07 in the first cut to $26.24 \%$ in the second cut over the two season (Table 4). The decline in crude fiber of barley may be explained by thinned stem and /or better leaf / stem ratio in successive cuttings. These results can be supported by those of crude protein in the same table. Crude fiber of berseem clover, averaged over cultivars, ranged from 20.14 in the first cut to $23.78 \%$ in the forth cut over the two season 
(Table 4). Helaly berseem cultivar had the highest crude fiber of pure stand ranged from 20.14 in the first cut to $23.78 \%$ in the forth cut over the two season (Table 4). The increase in crude fiber of berseem over time can be explained by leaf defoliation and / or increase in stem portion of the stand (Table 4). Crude fiber of intercropped barley with berseem, averaged over intercropping ranged from 25.26 in the first cut to $12.63 \%$ in the forth cut. While, the best intercropping was Giza 129 (75\% hull-less barley cultivar with $25 \%$ Sakha 4 berseem cultivar) ranged from 31.31 in the first cut to $21.38 \%$ in the forth cut over the two season (Table 4). These results are in agreement with those obtained by Helmy et al., (2011).

\section{Ash\%}

Barley cultivars in pure stand had high percentages of ash than berseem cultivars. These percentages slightly decreased by successive cuts. Barley cv. (Giza 134) had the highest ash content from the first cut 17.34 to second cut $16.24 \%$ (Table 4). On the other hand, the best averaged over intercropping of berseem with barley had Giza 129 (75\% hull-less barley) with 25\% Helaly berseem cultivar ranged from 16.49 in the first cut to $13.22 \%$ in the forth cut over the two seasons (Table 4). These results confirmed the finding of Abdel-Aziz et al., (2007).

\section{Calcium and phosphorus}

Calcium ( $\mathrm{Ca}$ ) and phosphorus (P) concentrations were determined in the harvested plant (Table 5). Barley and berseem in sole were inferior in the first and second cut with respect to phosphorus. However, no considerable differences were detected in the third or fourth cuts. Sole berseem possessed higher calcium level that ranged from 1.97 in the first to $2.02 \%$ in the last cut c v Sakha4 and c v Helaly in sole possessed higher calcium level that ranged from 1.91 in the first cut to $1.87 \%$ in the forth cut. The highest value was recognized for Giza 133 at sole at the first and second cuts ( 0.75 to 0.50 ) over two seasons. The highest value of intercropping by25\% G.133- Sakha 4 (75\%) over two season. Also, phosphorus (P) concentrations were determined in the harvested plants (Table 5). Berseem in sole possessed higher phosphorus $(P)$ concentration that ranged from 0.33 in the first to $0.27 \%$ in the forth cut c v Sakha4. The highest value was of intercropping by $25 \%$ G.133- Sakha4 $75 \%$ at combined over the two season. $\mathrm{Ca} / \mathrm{P}$ ratio ranged from 1.97 to 1.43 for sole barley cV Giza 133 and from 6.97 to 8.90 for sole berseem cv sakha4. the highest value of intercropping by $25 \%$ G.133- Sakha4 (75\%) at over two seasons. 
Table 4. Mean of protein, fiber and ash (\%) at the four cutting of four barley and two berseem clover cultivars under intercropping systems (I. S) in combined over the two season.

\begin{tabular}{|c|c|c|c|c|c|c|c|c|c|c|c|c|c|}
\hline \multirow[b]{2}{*}{ Treatments } & \multirow{2}{*}{ I. S } & \multicolumn{4}{|c|}{ \%Protein } & \multicolumn{4}{|c|}{$\%$ Fiber } & \multicolumn{4}{|c|}{$\%$ Ash } \\
\hline & & Cut 1 & Cut 2 & Cut 3 & Cut 4 & Cut 1 & Cut 2 & Cut 3 & Cut 4 & Cut 1 & Cut 2 & Cut 3 & Cut 4 \\
\hline \multirow{2}{*}{$\begin{array}{l}\text { Sole barley } \\
\text { G.133 } \\
\text { G.134 } \\
\text { G.129 } \\
\text { G.130 } \\
\text { Sole berseem } \\
\text { Sakha 4 } \\
\text { Helaly }\end{array}$} & $\begin{array}{l}100 \% \\
100 \% \\
100 \% \\
100 \%\end{array}$ & $\begin{array}{l}11.63 \\
11.35 \\
12.85 \\
12.45\end{array}$ & $\begin{array}{l}11.89 \\
12.01 \\
13.02 \\
12.36\end{array}$ & $\begin{array}{l}- \\
\overline{-} \\
-\end{array}$ & $\begin{array}{l}- \\
- \\
-\end{array}$ & $\begin{array}{l}29.07 \\
29.86 \\
29.36 \\
26.24\end{array}$ & $\begin{array}{l}25.89 \\
26.72 \\
24.35 \\
22.07\end{array}$ & \multirow{2}{*}{$\begin{array}{c}- \\
- \\
- \\
21.75 \\
23.09\end{array}$} & \multirow{2}{*}{$\begin{array}{c}- \\
- \\
- \\
23.78 \\
23.83\end{array}$} & $\begin{array}{l}16.73 \\
17.32 \\
15.59 \\
15.50\end{array}$ & \multirow{2}{*}{$\begin{array}{l}15.35 \\
16.24 \\
14.46 \\
14.21 \\
13.47 \\
12.90\end{array}$} & \multirow{2}{*}{$\begin{array}{c}- \\
- \\
- \\
13.00 \\
12.30\end{array}$} & \multirow{2}{*}{$\begin{array}{c}- \\
- \\
- \\
- \\
12.73 \\
12.96\end{array}$} \\
\hline & $\begin{array}{l}100 \% \\
100 \%\end{array}$ & $\begin{array}{l}16.65 \\
16.98\end{array}$ & $\begin{array}{l}15.21 \\
15.89\end{array}$ & $\begin{array}{l}14.00 \\
14.13\end{array}$ & $\begin{array}{l}12.21 \\
13.01\end{array}$ & $\begin{array}{l}19.00 \\
20.14\end{array}$ & $\begin{array}{l}20.65 \\
21.57\end{array}$ & & & $\begin{array}{l}14.66 \\
14.11\end{array}$ & & & \\
\hline $\begin{array}{l}\text { Intercrops } \\
\text { G.133- Sakha } 4 \\
\text { G.133- Sakha } 4 \\
\text { G.133- Sakha } 4 \\
\text { G.133- Helaly } \\
\text { G.133- Helaly } \\
\text { G.133- Helaly } \\
\text { G.134- Sakha } 4 \\
\text { G.134- Sakha } 4 \\
\text { G.134- Sakha } 4 \\
\text { G.134- Helaly } \\
\text { G.134- Helaly } \\
\text { G.134- Helaly } \\
\text { G.129- Sakha } 4 \\
\text { G.129- Sakha } 4 \\
\text { G.129- Sakha } 4 \\
\text { G.129- Helaly } \\
\text { G.129- Helaly } \\
\text { G.129- Helaly } \\
\text { G.130- Sakha } 4 \\
\text { G.130- Sakha } 4 \\
\text { G.130- Sakha } 4 \\
\text { G.130- Helaly } \\
\text { G.130- Helaly } \\
\text { G.130- Helaly }\end{array}$ & $\begin{array}{l}75-25 \% \\
50-50 \% \\
25-75 \% \\
75-25 \% \\
50-50 \% \\
25-75 \% \\
75-25 \% \\
50-50 \% \\
25-75 \% \\
75-25 \% \\
50-50 \% \\
25-75 \% \\
75-25 \% \\
50-50 \% \\
25-75 \% \\
75-25 \% \\
50-50 \% \\
25-75 \% \\
75-25 \% \\
50-50 \% \\
25-75 \% \\
75-25 \% \\
50-50 \% \\
25-75 \%\end{array}$ & $\begin{array}{l}12.07 \\
12.88 \\
14.54 \\
12.03 \\
12.76 \\
13.75 \\
11.96 \\
12.01 \\
13.41 \\
11.46 \\
12.15 \\
13.09 \\
12.20 \\
12.87 \\
13.55 \\
12.71 \\
13.13 \\
14.33 \\
12.14 \\
12.76 \\
13.54 \\
12.40 \\
12.53 \\
13.09\end{array}$ & $\begin{array}{l}12.87 \\
13.43 \\
15.32 \\
12.75 \\
13.14 \\
14.54 \\
12.80 \\
12.97 \\
14.52 \\
11.98 \\
12.95 \\
14.12 \\
12.75 \\
13.10 \\
14.46 \\
13.27 \\
14.76 \\
15.02 \\
12.78 \\
13.17 \\
14.35 \\
12.87 \\
13.19 \\
13.79\end{array}$ & $\begin{array}{l}11.45 \\
12.71 \\
13.22 \\
11.03 \\
12.35 \\
12.87 \\
11.63 \\
12.03 \\
13.72 \\
11.11 \\
12.14 \\
13.04 \\
12.04 \\
12.73 \\
13.68 \\
12.17 \\
13.98 \\
14.29 \\
12.00 \\
12.62 \\
12.06 \\
11.19 \\
12.79 \\
12.23\end{array}$ & $\begin{array}{l}10.66 \\
11.21 \\
12.17 \\
10.26 \\
11.14 \\
11.43 \\
11.01 \\
11.45 \\
12.30 \\
10.21 \\
11.17 \\
12.67 \\
11.53 \\
11.75 \\
12.87 \\
11.60 \\
13.09 \\
13.77 \\
11.52 \\
12.00 \\
11.14 \\
10.23 \\
11.12 \\
12.03\end{array}$ & $\begin{array}{l}16.18 \\
15.10 \\
15.95 \\
19.00 \\
15.07 \\
13.63 \\
19.21 \\
20.55 \\
16.74 \\
20.18 \\
18.33 \\
16.00 \\
21.38 \\
16.80 \\
14.36 \\
17.41 \\
15.23 \\
13.07 \\
17.29 \\
15.64 \\
13.88 \\
15.11 \\
16.35 \\
12.63\end{array}$ & $\begin{array}{l}18.88 \\
17.55 \\
16.62 \\
19.62 \\
18.10 \\
15.44 \\
20.61 \\
21.12 \\
17.80 \\
22.78 \\
20.58 \\
17.38 \\
22.85 \\
17.41 \\
15.78 \\
18.84 \\
16.38 \\
14.37 \\
18.44 \\
17.68 \\
16.00 \\
17.51 \\
19.14 \\
15.00\end{array}$ & $\begin{array}{l}22.12 \\
20.86 \\
19.10 \\
23.12 \\
21.34 \\
22.25 \\
25.32 \\
24.69 \\
21.68 \\
26.95 \\
25.32 \\
21.72 \\
27.58 \\
25.98 \\
20.11 \\
23.50 \\
20.08 \\
18.10 \\
20.89 \\
19.79 \\
18.56 \\
18.49 \\
20.73 \\
16.34\end{array}$ & $\begin{array}{l}25.26 \\
24.42 \\
22.96 \\
26.12 \\
25.18 \\
24.83 \\
27.70 \\
26.58 \\
24.60 \\
31.12 \\
29.71 \\
25.99 \\
31.31 \\
29.83 \\
23.97 \\
27.12 \\
22.54 \\
20.44 \\
22.92 \\
22.72 \\
19.52 \\
21.83 \\
24.98 \\
23.78\end{array}$ & $\begin{array}{l}15.62 \\
13.76 \\
12.78 \\
15.38 \\
13.29 \\
11.78 \\
14.76 \\
13.28 \\
12.88 \\
14.88 \\
13.28 \\
12.48 \\
16.13 \\
14.21 \\
13.91 \\
16.49 \\
14.29 \\
14.09 \\
15.40 \\
14.79 \\
13.92 \\
12.98 \\
11.58 \\
11.05\end{array}$ & $\begin{array}{l}14.47 \\
12.84 \\
12.32 \\
14.74 \\
12.84 \\
12.32 \\
14.74 \\
12.45 \\
12.00 \\
14.10 \\
13.05 \\
12.25 \\
13.92 \\
13.00 \\
12.25 \\
15.05 \\
13.39 \\
12.81 \\
14.70 \\
13.88 \\
12.80 \\
12.21 \\
11.35 \\
11.02\end{array}$ & $\begin{array}{l}14.00 \\
12.40 \\
11.88 \\
13.48 \\
12.20 \\
11.20 \\
13.51 \\
11.91 \\
11.96 \\
13.68 \\
12.33 \\
11.11 \\
13.23 \\
12.65 \\
12.00 \\
14.66 \\
12.08 \\
11.21 \\
14.00 \\
12.35 \\
11.66 \\
11.01 \\
11.12 \\
10.20\end{array}$ & $\begin{array}{l}11.74 \\
11.04 \\
10.69 \\
11.42 \\
11.83 \\
10.27 \\
12.11 \\
11.65 \\
11.51 \\
12.95 \\
11.85 \\
10.92 \\
12.84 \\
12.06 \\
11.66 \\
13.22 \\
11.40 \\
10.34 \\
12.35 \\
11.23 \\
10.13 \\
11.00 \\
10.53\end{array}$ \\
\hline \multicolumn{2}{|c|}{$\begin{array}{l}\text { G.130- Helaly } \\
\text { C.V\% }\end{array}$} & 5.36 & 8.37 & 6.81 & 11.53 & 10.65 & 11.73 & 7.33 & 9.73 & 4.68 & 7.27 & 6.87 & 9.88 \\
\hline \multirow{2}{*}{\multicolumn{2}{|c|}{$\begin{array}{r}\text { L.SD at } 005 \text { for Trea } \\
\text { Cut (C) }\end{array}$}} & 1.55 & 1.24 & 1.49 & 0.65 & 1.13 & 1.05 & 2.44 & 2.05 & 1.07 & 0.96 & 0.82 & 1.31 \\
\hline & & 1.24 & 1.07 & 1.27 & 1.91 & 2.37 & 2.49 & 1.82 & 1.60 & 0.97 & 1.44 & 0.97 & 1.04 \\
\hline \multicolumn{2}{|c|}{$\begin{array}{c}\text { Cut (C) } \\
\text { TXC } \\
\end{array}$} & 1.50 & 1.21 & 1.44 & 0.60 & 1.99 & 1.02 & 2.37 & 1.99 & 1.04 & 0.93 & 0.79 & 1.27 \\
\hline
\end{tabular}


Table 5. Mean of calcium, phosphors percentage and Ca / P ratio of forge crops as affected by sole and constituents (\%) for the four cuts of four barley and two berseem clover cultivars under intercropping systems (I. S) in combined over the two season.

\begin{tabular}{|c|c|c|c|c|c|c|c|c|c|c|c|c|c|}
\hline \multirow[b]{2}{*}{ Treatments } & \multirow[t]{2}{*}{ I. S } & \multicolumn{4}{|c|}{ \%Calcium } & \multicolumn{4}{|c|}{ \%Phosphors } & \multicolumn{4}{|c|}{ Ratio $\mathrm{Ca} / \mathrm{P}$} \\
\hline & & Cut 1 & Cut 2 & Cut 3 & Cut 4 & Cut 1 & Cut 2 & Cut 3 & Cut 4 & Cut 1 & Cut 2 & Cut 3 & Cut 4 \\
\hline \multicolumn{14}{|l|}{ Sole barley } \\
\hline G.133 & $100 \%$ & 0.75 & 0.50 & - & - & 0.38 & 0.35 & - & - & 1.97 & 1.43 & - & - \\
\hline G.134 & $100 \%$ & 0.63 & 0.41 & - & - & 0.35 & 0.34 & - & - & 1.80 & 1.21 & - & - \\
\hline G.129 & $100 \%$ & 0.70 & 0.48 & - & - & 0.28 & 0.26 & - & - & 2.50 & 1.85 & - & - \\
\hline G.130 & $100 \%$ & 0.57 & 0.35 & - & - & 0.20 & 0.22 & - & - & 2.85 & 1.59 & - & - \\
\hline \multicolumn{14}{|l|}{ Sole $b$ berseem } \\
\hline Sakha 4 & $100 \%$ & 1.97 & 1.90 & 2.10 & 2.02 & 0.33 & 0.31 & 0.30 & 0.27 & 6.97 & 833 & 7.00 & 8.90 \\
\hline Helaly & $100 \%$ & 1.91 & 1.75 & 2.00 & 1.87 & 0.30 & 0.30 & 0.33 & 0.21 & 6.37 & 6.13 & 6.06 & 7.44 \\
\hline \multicolumn{14}{|l|}{ Intercrops } \\
\hline G.133- Sakha 4 & $75-25 \%$ & 1.07 & 1.17 & 1.45 & 1.66 & 0.28 & 0.24 & 0.22 & 0.18 & 3.82 & 4.88 & 6.59 & 9.22 \\
\hline G.133- Sakha 4 & $50-50 \%$ & 1.28 & 1.34 & 1.71 & 1.81 & 0.42 & 0.35 & 0.30 & 0.25 & 3.05 & 3.83 & 5.70 & 7.24 \\
\hline G.133- Sakha 4 & $25-75 \%$ & 1.45 & 1.52 & 1.83 & 1.92 & 0.48 & 0.41 & 0.35 & 0.30 & 3.02 & 3.71 & 5.23 & 6.40 \\
\hline G.133- Helaly & $75-25 \%$ & 1.20 & 1.27 & 1.55 & 1.79 & 0.24 & 0.29 & 0.23 & 0.19 & 5.00 & 4.38 & 6.74 & 9.42 \\
\hline G.133- Helaly & $50-50 \%$ & 1.01 & 1.31 & 1.35 & 1.77 & 0.20 & 0.20 & 0.18 & 0.15 & 5.05 & 6.55 & 7.50 & 11.80 \\
\hline G.133- Helaly & $25-75 \%$ & 1.11 & 1.45 & 1.56 & 1.60 & 0.31 & 0.25 & 0.24 & 0.22 & 3.58 & 5.80 & 6.50 & 7.27 \\
\hline G.134- Sakha 4 & $75-25 \%$ & 1.19 & 1.28 & 1.63 & 1.74 & 0.26 & 0.24 & 0.20 & 0.19 & 4.58 & 5.33 & 8.15 & 9.16 \\
\hline G.134- Sakha 4 & $50-50 \%$ & 1.21 & 1.44 & 1.52 & 1.59 & 0.32 & 0.29 & 0.27 & 0.24 & 3.78 & 4.97 & 5.63 & 6.63 \\
\hline G.134- Sakha 4 & $25-75 \%$ & 1.03 & 1.24 & 1.37 & 1.44 & 0.45 & 0.40 & 0.37 & 0.34 & 2.29 & 3.10 & 3.70 & 4.24 \\
\hline G.134- Helaly & $75-25 \%$ & 1.10 & 1.36 & 1.44 & 1.59 & 0.20 & 0.19 & 0.17 & 0.14 & 5.50 & 7.16 & 8.47 & 11.36 \\
\hline G.134- Helaly & $50-50 \%$ & 1.17 & 1.40 & 1.50 & 1.63 & 0.22 & 0.20 & 0.19 & 0.18 & 5.32 & 7.00 & 7.89 & 9.06 \\
\hline G.134- Helaly & $25-75 \%$ & 1.33 & 1.37 & 1.41 & 1.66 & 0.35 & 0.30 & 0.27 & 0.24 & 3.80 & 4.57 & 5.22 & 6.92 \\
\hline G.129- Sakha 4 & $75-25 \%$ & 1.10 & 1.20 & 1.24 & 1.54 & 0.26 & 0.25 & 0.21 & 0.17 & 4.23 & 4.80 & 5.90 & 9.06 \\
\hline G.129-Sakha 4 & $50-50 \%$ & 1.15 & 1.30 & 1.44 & 1.57 & 0.30 & 0.27 & 0.24 & 0.22 & 3.83 & 4.81 & 6.00 & 7.14 \\
\hline G.129- Sakha 4 & $25-75 \%$ & 1.35 & 1.44 & 1.50 & 1.80 & 0.33 & 0.30 & 0.29 & 0.26 & 4.09 & 4.80 & 5.17 & 6.92 \\
\hline G.129- Helaly & $75-25 \%$ & 1.12 & 1.27 & 1.30 & 1.62 & 0.19 & 0.17 & 0.14 & 0.14 & 5.89 & 7.47 & 9.29 & 11.57 \\
\hline G.129- Helaly & $50-50 \%$ & 1.20 & 1.43 & 1.49 & 1.55 & 0.21 & 020 & 0.16 & 0.15 & 5.71 & 0.07 & 9.31 & 10.33 \\
\hline G.129- Helaly & $25-75 \%$ & 1.04 & 1.15 & 1.29 & 1.37 & 0.44 & 0.18 & 0.15 & 0.13 & 2.36 & 6.39 & 8.60 & 10.54 \\
\hline G.130- Sakha 4 & $75-25 \%$ & 1.11 & 1.20 & 1.22 & 1.31 & 0.20 & 0.19 & 0.17 & 0.16 & 5.55 & 6.32 & 7.18 & 8.19 \\
\hline G.130- Sakha 4 & $50-50 \%$ & 1.17 & 1.22 & 1.34 & 1.44 & 0.33 & 0.31 & 0.29 & 0.25 & 3.55 & 3.94 & 4.62 & 5.76 \\
\hline G.130- Sakha 4 & $25-75 \%$ & 1.29 & 1.34 & 1.41 & 1.50 & 0.40 & 0.37 & 0.35 & 0.31 & 3.23 & 3.62 & 4.03 & 4.84 \\
\hline G.130- Helaly & $75-25 \%$ & 1.09 & 1.15 & 1.25 & 1.29 & 0.19 & 0.17 & 0.15 & 0.13 & 5.74 & 6.76 & 8.33 & 9.92 \\
\hline G.130- Helaly & $50-50 \%$ & 1.14 & 1.19 & 1.27 & 1.36 & 0.25 & 0.23 & 0.20 & 0.17 & 4.56 & 5.17 & 6.35 & 8.00 \\
\hline G.130- Helaly & $25-75 \%$ & 1.20 & 1.37 & 1.39 & 1.53 & 0.33 & 0.30 & 0.27 & 0.24 & 3.64 & 4.57 & 5.15 & 6.38 \\
\hline \multicolumn{2}{|c|}{ C.V\% } & 1.52 & 1.69 & 1.88 & 1.75 & 2.33 & 4.12 & 3.44 & 4.56 & 2.63 & 2.28 & 7.33 & 5.40 \\
\hline \multicolumn{2}{|c|}{ L.SD at 005 for Treatments $(\mathrm{T})$} & 0.44 & 0.34 & 0.55 & 0.79 & 0.56 & 0.65 & 0.30 & 0.19 & 2.22 & 3.44 & 2.87 & 1.31 \\
\hline \multirow{2}{*}{\multicolumn{2}{|c|}{ Cut (C) }} & 0.21 & 0.10 & 0.14 & 0.22 & 0.47 & 1.82 & 2.49 & 2.37 & 0.97 & 1.44 & 0.97 & 4.21 \\
\hline & & 1.11 & 1.32 & 1.55 & 1.75 & 0.87 & 1.23 & 1.33 & 1.54 & 1.36 & 2.93 & 2.79 & 3.27 \\
\hline
\end{tabular}




\section{CONCLUSION}

The results of this study indicated that intercropping barley with berseem clover at the seeding rate of $12.5-18.75$ seeds $\mathrm{kg} / \mathrm{fad}^{-1}$ (25-75\%) provided the greatest advantage in fresh forage, dry forage and protein production. Consequently, the barley-berseem clover intercrop at seeds $12.5-18.75$ seeds $\mathrm{kg} / \mathrm{fad}^{-1}(25-75 \%)$ should be used in Mediterranean short-season growing environments as alternative of berseem clover sole crop for high forage and protein yield with more balanced nutritive value.

\section{REFERENCES}

1. Abdel-Aziz, T. K; A. A. El-Shereif, M. M. Azab and N. M. Hamed. 2007. Influence of seeding rates and $\mathrm{N}$ fertilizer on forage yield and quality of berseem-ryegrass mixture. J. Agric. Sci. Mansoura Univ., 32 (2): 1583-1600.

2. Anil, L., J. Park, R.H. Phipps and F.A. Miller. 1998. Temperate intercropping

a. of cereals for forage: A review of the potential for growth and utilization

b. with particular reference to the UK. Grass Forage Sci. 53:301-317.

A. O. A. C. 1990. Official Methods of Analysis. Association of official Analysis chemists. $11^{\text {th }}$ Ed., P. O. Box 540, Washington, D. C., USA.

3. Caballero R., Goicoechea E. L. and Hernaiz P. J. 1995. Forage yields and quality of common vetch and oat sown at varying seeding ratios and seeding rates of vetch. Field Crops Res. 41:135-140.

4. Campillo, R., S. Urquiaga, P. Undurraga, I. Pino, and R.M. Boddey. 2005. Strategies to optimise biological nitrogen fi xation in legume/grass pastures in the southern region of Chile. Plant Soil 273:57-67.

5. Gomez, K.A. and A.A.Gomez. 1984. Statistical procedures for agricultural research John Wiley and Sons, New York.

6. Hall, D.D., G.L. Cromwell, and T.S. Stahly. 1991. Effects of dietary calcium, phosphorus, calcium: phosphorus ratio and vitamin $\mathrm{K}$ on performance, bone strength and blood clotting status of pigs. J. Anim. Sci. 69:646-655

7. Helmy, Amal, A., A., Wafaa M. Sharawy and Hoda I. M. Ibrahim. 2011. Evaluation of fodder yield and its quality of barley and with berseem clover. J. Plant production, Mansoura Univ., Vol. 2 (7): 851-863.

8. Lawes, D.A., and D.I.H. Jones. 1971. Yield, nutritive value and ensiling characteristics of whole-crop spring cereals. J. Agric. Sci. 76:479-485. 
9. Martiniello, P. 1999. Effects of irrigation and harvest management on dry matter yield and seed yield of annual clovers grown in pure stand and in mixtures with graminaceous species in the Mediterranean environment. Grass Forage Sci. 54:52-61.

a. McAndrews, G. M., Franke, K., Moore, K. and George, R. 2004. Forage yield and nutritive value of oat interseeded with berseem clover and barley. On line Crop Management doi: 10. 1094/CM-2004-0301-01-RS. 191:195-201.

b. Norman, L.M., and P.G. Jarvis. 1975. Photosynthesis in Sitka spruce [Picea sitchensis (Bong.) Carr.] III. Measurements of canopy structure and interception of radiation. J. Appl. Ecol. 12:839-878.

10. Osman, A.E., and N. Nersoyan. 1986. Eff ect of the proportion of species on the yield and quality of forage mixtures, and on the yield of barley in the following year. Exp. Agric. 22:345-351.

11. Papastylianou, I. 2004. Eff ect of rotation system and $\mathrm{N}$ fertilizer on barley and common vetch grown in various crop combinations and cycle lengths. J. Agric. Sci. 142:41-48.

12. Robinson, R.C. 1969. Annual legume:cereal mixtures for forage and seed. Agron. J. $61: 759-761$.

13. Ross, S.M., J.R. King, J.T. O'Donovan, and D. Spaner. 2004a. Forage potential of intercropping berseem clover with barley, oat, or triticale. Agron. J. 96:10131020.

14. Ross, S.M., J.R. King, J.T. O'Donovan, and D. Spaner. 2004b. Intercropping berseem clover with barley and oat for forage. Agron. J. 96:1719-1729.

15. Snedecor, G. W. Cochran. 1980. Statistical Methods, $7^{\text {th }}$ Ed. 507 pp. lowa State Univ. Press, Ames lowa. USA. 


\section{تحميل الثعير مع البرسيم المصرى تحت معدلات تقاوى مختلفة}

\section{فادية محمد سلطان' وفاء وهبة محمد شافعى}

ا ـ قسم بحوث محاصيل العلف- معهد بحوث المحاصيل الحقلية - مركز البحوث الزراعية -

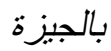

r ـ المعدل المركزى لبحوث التصميم و التحليل الأحصائى - مركز البحوث الزراعية - بالجيزة

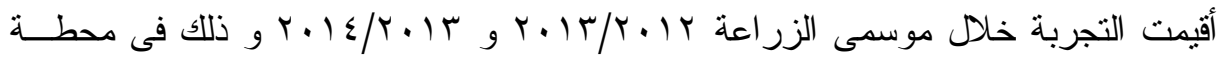

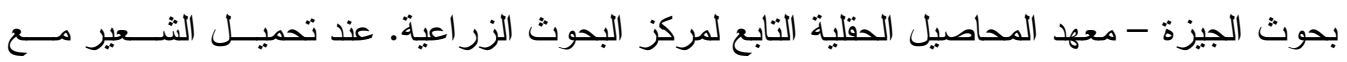

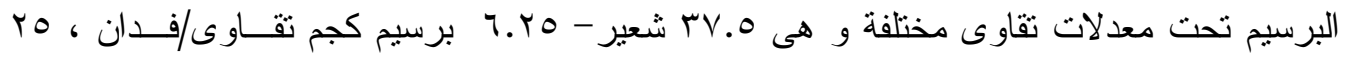

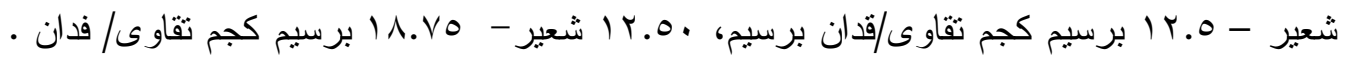

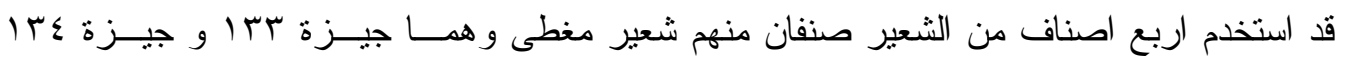

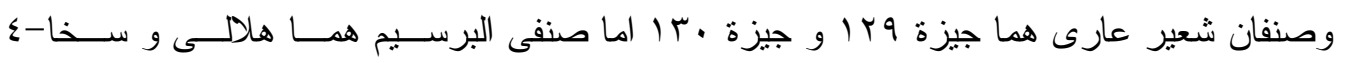

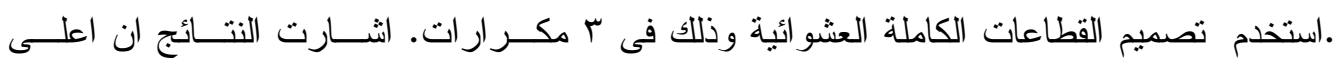

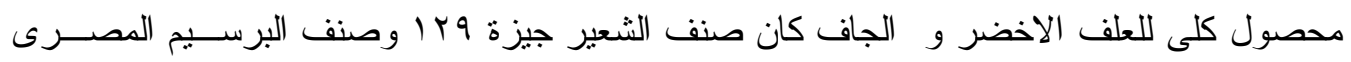

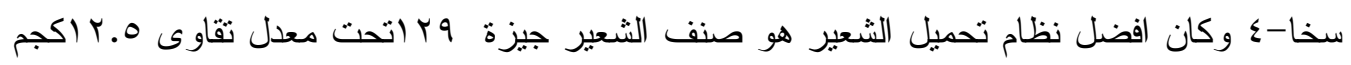

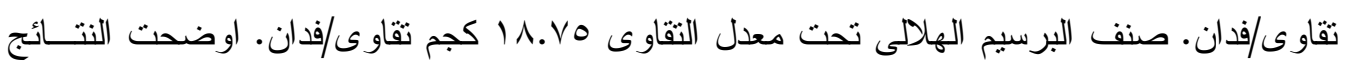

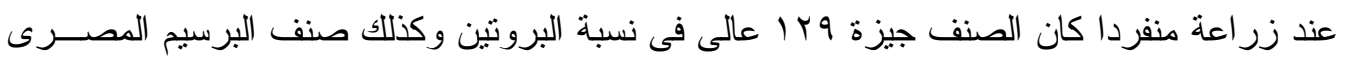

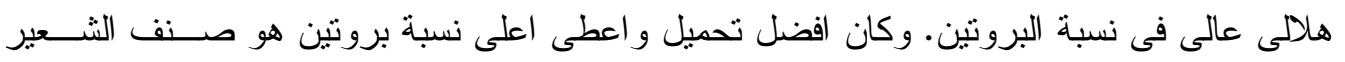

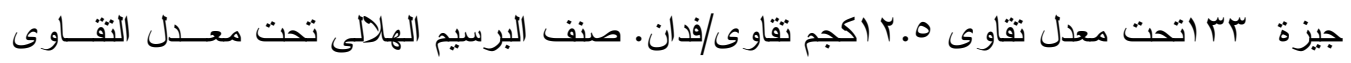

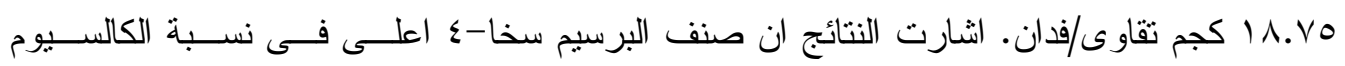

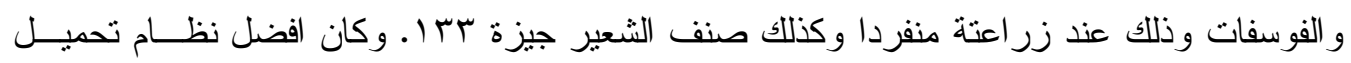

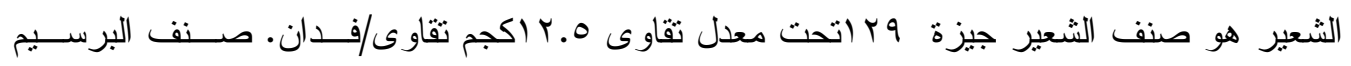

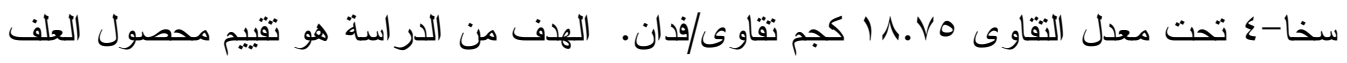

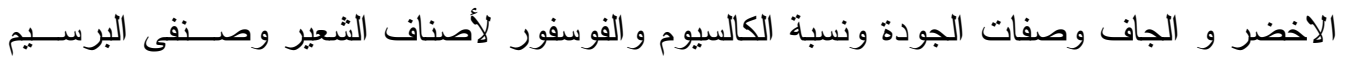
المصرى عند زر اعتهما منفردا و محملا وذلك تحت ثلاث معدلات تقاوى مختلفة. 